\section{OVERNAME VAN AFFAIRES}

In het volgende wensehen wij een en ander op te merken over den verkoop van affaires, de z.g. overdracht van zaken, uit juridisch oogpunt beschouwd. Het opzet wordt gesproken van affaires en nict van zalien, ondat dit laatste woord in vele beteckenissen wordt gebruikt; het woord zaak is ecn algemeen begrip (genus), het woord affaire dus een speciaal begrip (species). In de praktijk hoort men echter bijna steeds spreken van de overdracht van zaken en bedoelt hier dan mee, dat nen verkoopt de tot heden door den verkooper gedreven zaak. Dat de aceountant met mulke transacties veelvuldig in ammaking komt, behoeven wij slechts aan te stippen, en dat hij hierbij dikwijls ecn belangrijke taak heeft te vervullen, het is overbekend.

Om niet te uitgebreid te worden en niet in te lastige kwasties te vallen, zullen wij het alleen hebben over de overdracht van een affaire, waarvan ecn enkel persoon de eigenaar is (z.g. eenmansonderneming).

De ecrste vraag, welke men zich kan stellen is : of een affaire juridisch wel cen zaak is. Prof. Schollen ${ }^{1}$ ) meent dat de vraag aanleiding geeft tot twee andere nl.: Bestaat er een recht op een bepaald bedrijf? Hoe daar over gedacht en geoordeeld werd, is van gecn betcekenis, tegenwoordig moet de vraag zonder twijfel bevestigend beantwoord worden.

Dat er een recht op een handelszaak kan zijn, blijkt uit verschillende artikelen van de Handelsregisterwet (1918) ${ }^{2}$ )

Dat zulk een handelszaak kan worden overgedragen, blijkt zeer beslist uit de Handelsnaamwet (1921), daarin staat uitdrukkelijk, dat een handelsnaam kan worden overgedragen maal alleen in verbinding met de handelszaal: (Art. 2).

Het zelfde wordt bepaald voor een merk in art. 20 van de Merkenwet.

Wanncer wij het hierover nu eens zijn, volgt daaruit dan logisch, dat ook cen affaire en zelfstandig vermogensbestanddeel is? Dat is de twcede vraag, welke wij moeten beantwoorden. Wij hebben het cr natuurlijk niet over, of de eigenaar van de affaire het als zoodanig beschouwt, dit hebben wij bij de eerste boekhoudlessen geleerd. Ieder hecft het recht een gedeelte van zijn vermogen af te zonderen, dat b.v. afzonderlijk te administreeren; maar juridisch blijft het in het algemeen een deel van zijn gehecle vermogen uitmaken.

Wanneer wij ecn affaire - voor de eenmanszaak zeker zeer twijfelachtig - als een zelfstandig vermogensbestanddeel zouden kummen opratten, dan zou dit dus ook inhouden, dat de jechten en verplichtingen, welke te zamen het bedrijf vormen, ook als een geheel beschouwd mocten worden. Dit nu moet beslist ontkennend beantwoord worden. Het recht op een handelsnaam - ook al gaat deze in rechten niet over, zonder dat de zaak mede overgaat - sluit nog geenszins in zich het recht op do positieve vermogensbestanddeelen van die zaak en de verplichting om de negatieve vermogensbestanddeelen ten laste van hem, die de affaire overneemt, te brengen. Juridisch is een affairc niet te boschouwen als een afgezonderd gedeclte van het vermogen, een afzonderlijk reehtsolject. Dit is vooral van beteekenis bij een eventuecl faillissement van den eigenaar der affaire; schuldeischers der zaak zijn nict bevoorrecht op de activa van dic zaak, zij deelen gelijk op met de particulicre schuldeischers van den eigenaar. Een ander gevoly is dat dus volgens Nederlandsch recht een affaire niet verpand kan worden, natuurlijk wel de bestanddeelen der handelszaak. Voor elk positief en negatief vermogensbestanddeel van cen handelszak zal dus afzon-

1) Asser-Scholten 2 de deel, 6de druk, blz. 8 e.v

2) Men zie b.v. art. 8 le lid: Behoort de handelszaak aan een naanlooze vennootschap; art. 9 , art. 10 , art. 11 , art. 12 . derlijk dienen te worden nagegaan, hoe het recht en de verplichting voor den nieuwen eigenar worden verkregen of ontstaan, hicraan wordt in de praktijk niet steeds gedacht.

Wamneer wij dat $n$ steeds goed in het oog houden, dan kunnen wij nagaan, hoe eenige, in bijna elke zaak voorkomende vermogensbestandelelon, worden overgedıagen en de verplichtingen overgenomen.

Ilet cenvoudigst gaut liet met de roerende goederen en de toonderpapieren. Hiervan gaat de eigendom over door eenvoudige overgifte. De juridische kwesties, welke hier kumnen ontstaan, kunnen bij clke overdracht van dit soort zaken plaats hebben, hierop verder in te gaan, valt buiten het bestek van dit artikel.

De debiteuren gaan allecn dan op den nieuwen eigenaar over, wamneer in acht is genomen art. $668 \mathrm{~B}$. W. Het recht op de volderingen wordt overgedragen door middel van een authenticke- of onderhandsche akte. Aangezien de akte hier solemnitatis causa ${ }^{1}$ ) dient, gaat de eigendom zonder zulk een geschrift in geen geval over. Zoodra de overdracht op deze wijze heeft plaats gehad, geldt dit tegenover derden, tegenover hen is de nieuwe eigenaar van de affaire dus de rechthebbende. Echter niet tegenover den schuldenaar zelf, deze kan nog rechtsgeldig aan den ouden eigenaar betalen; alleen wanneer de overdracht aan hem beteekend is, of hij deze schriftelijk heeft aangenomen of erkend, is ook hij gebonden ten aanzien van den nieuwen eigenaal en kan alleen aan hem rechtsgeldig betalen.

Heeft de verkoopende eigenaar gelden onder hypothecair verband uitgeleend, dan kan hij — wamneer zij niets met de zaak te malien hebben - deze schuldvorderingen zelf houden; behooren zij echter min of meer ${ }^{2}$ ) bij de zaak, dan moeten zij met dezelfde formaliteiten, als hicrvoor bij de debiteuren besproken, worden overgedragen, alleen moet ook nog in de openbare register's de cessie worden aangeteekend.

De eigendom van de te innen wissels, gaat over door endossement gevolgd door overgifte of door enkele overgifte (wisscls met blanco endossement).

Ook bij de eigendomsoverdracht van de onroerende goederen behoeven wij niet lang stil te staan. Het valt buiten het bestek van dit artikel hierop diep in te gaan. Er kunnen hier echter juridische kwesties genoeg ontstaan. Wij volstaan met er op te wijzen, dat de eigendom van onroerende goederen - ook werkende tegenover derden - overgaat door overschrijving van de akte, welke van die overdracht wordt opgemaakt, in de openbare register's. Ofschoon niet noodzakelijk, verdient het aanbeveling hiervoor een notariëele akte op te laten maken.

I) vorderingen op bankinstellingen - tenzij deze worden overgenomen door den ouden eigenaar - gaan op dezelfde wijzo over als de vorderingen op debiteuren, alleen moet natuurlijk met de bank worden overeengekomen, dat zij ook met den nieuwen eigenaar in relatic wil komen te staan, dit is vooral van belang, wammeer erediet wordt gegeven; juridisch kan het recht voortvloeiend uit een credictovereenkomst niet gecedeerd worden ${ }^{3}$ ), dit is van te persoonlijk karakter. Bij de schulden hierover nog meer.

Bezit de overdragende cigenaar merken dan zal in de eerste plaats wel goed onderzocht mogen worden - en dit geldt ook voor octrooien - of formeel hicrmede alles in orde is. Er is wel

1) Men zegt dat een akte solemuitatis causa dient, wanneer zonder de akte het verlangde rechtsgevolg niet in kan treden. Dient de akte alleen tot bewijs, dan zegt men dat zij probationis causa wordt opgemakkt. Natuurlijk kan eerstgenoemde akte bovendien als bewijsmiddel dienen.

$\left.{ }^{2}\right)$ Zoo leenen in de praktijk sommige zaken onder hypothecair verhand on daardoor invloed op de geldleenende zaken uit te kunnen oefenen en haar debiet te vergrooten.

3) Zie Asser-Goudoever III blz. 100 
aan te denken, dat het recht op een merk altijd nog kan blijken aan cen ander toe te behooren, wannocr die slechts kan bewijzen de eerste gebruiker te zijn geweest. De inschrijving in de registers van het Bureau voor den Industrieelen Figendom goldt slechts als een vermoeden, dat men de cerste gebruiker van het merk is geweest. ${ }^{1}$ ) Daar een merk slechts kan overgaan met de handelszaak zelf, heeft de aanteekening in de registers bij het Burcau voor den Industrieelen Eigendom slechts plaats, wanneer een gewaalmerkt uittreksel van de akte, waaruit de overgang van de zaak blijkt, wordt overgelegd.

De overdracht van het octrooi, alsmede van het recht, voortvlociende nit de oetrooi-aanviage, heeft plaats bij cen akte. Toganover derden werkt de over(l'acht eerst, wammeer ce akte in het clarvoor bestemde register van den octrooiraad is ingeschreven.

Wat de schulden betıeft deze kunnen door den nieuwen eigenaar worden overgenomen, ${ }^{2}$ ) d.w.z. de nicuwe eigenaar neemt op zich on de schulden van de door hem overgenomen zaak in de plats van den ouden eigenaar te betalen. (art. $1449 \mathrm{~B} . \mathrm{W}$. ten $3 \mathrm{de}$, vide art. $1453 \mathrm{~B}$.W.). Daartoe is noodig de medewerking van den schuldeischer. Wordt de oude schuldenaar van zijn verbintenis niet uitdrukkelijk door den schuldeischer ontslagen, dan blịft hij verbonden en heeft de schuldeischer ook nog het recht om den nieuwen cigenaar tot betaling aan te spreken (beding ten behoeve van een derde).

Aangezien de schuldvernieuwing niet wordt verondersteld maar uitdrukkelijk uit de handeling moet blijken ${ }^{3}$ ) en om vast te stellen, dat geen beding ten bchoeve van een derde wordt gewenscht, is het aan te bevelen van de gesloten overeenkomst een akte op te maken. In de praktijk hebben wijj dikwijls gezien, dat een schriftelijke overcenkomst ontrent deze schuldvernieuwing wordt nagelaten. Het laat zich begrijpen, dat een en ander aanleiding kan geven tot moeilịkheden. Zoo ziet men in notariëele akten wel staan bij scheiding en decling: comparant $\Lambda$. neemt voor zijn rekening de schuld aan $\mathrm{X}$. enz. Dat $\mathrm{X}$. hier geen genoegen mee behoeft te nemen, maar van elk der erfgenamen, indien hij dat wenseht, hun aandeel kan vorderen, wanneer het een gewone schuld is en hij A. niet credietwaardig genoeg vindt, zal na het hier niteengezette geen betoog meer behoeven (vide art. 1147 B. W.).

Bij schuldvernieuwing is verder nog te letten op art. 1458 B. W., waar er op gewezen wordt, dat bij de schuldvernieuwing ook de voorrechten en hypotheken te niet gaan. Dit is logisch, want de schuld gaat door de velnieuwing te niet en er ontstaat cen geheel nieuwe. Dit is een van de voornaamste verschillen tusschen cessic en schuldvernieuwing. Wanneer men aan de schuldrordering deze voorrechten wil laten behouden, dan moeten deze uitdrukkelijk worden voorbehouden (art. 1457 B. W.).

Wamnecr de bankschuld overgenomen wordt, goldt het hiervoorgezegde natuurlijk op dezelfde wijze. Het is hier echter een groot belang, of de bank ook met den nieuwen eigenaar zaken

1) Zie art. 10 Merkenwet 1893. Zie ook Polak, Handboek voor het Ned. Handels- en Faillissementsrecht, le deel, 4c druk blz. 169.

-) Hier is sprake van de z.g. schuldovername. Door sommige juristen is wel beweerd, dat onze wet eigenlijk geen schuldovername kent, aithins, geen reden van hestaan heeft nast de actieve schuldvernieuwing. Logisch staan wij in zooverre aan den kant van hen, die de schuldovername ontkennen, ondat alleen bij precies gelijke credietwaardigheid van den schuldenaar er sprake kan zijn van een schuldovername. Dit geval zal praktisch wel nooit voorkomen. De schuld kan door een ander voldaan worden, maar de .,Haftung" kan zonder overgang van het vermogen niet worden overgedragen; geheurt dit toch dan is er een nieuwe verbintenis ontstaan, m.a.w. schuldvernieuwing heeft plaats gehad. Vandaar dat wij hierboven de schuldovername hebben gegoten in den vorm van een schuldvernieuwing.

3) Zie art. 1451 B. W. Men lette er op dat ,akte" hier beteekent handeling. wenscht te doen, vooral wanncer de bankschuld cler affaire van beteekenis is. De groote banken zijn echter wel zoo goed ingejicht, om zelf goed op hun zaken te letten, meer in het bijzonder om na to gaan of de nieuwe eigenar we] voldnende zekerheid kan stellen; ook de juridisehe kant van de transactie zal door hen goed worden nagegaan.

Hecft cen zaak wissels to betalen, dan kan natuurlijk worden overecngekomen, dat de nieuwe cigenaar deze zal betalen. Ontslagen worden van zijn hoofdelijke wisselverbintenis kan de oude eigenail echter niet door den nieuwen eigenaar. Hij behoort tot het wisselpersoneel en is hoofdelijk voor de wisselverbinten is verbonden. Wanneer het mogelijk is, kunnen de wissels ten kantore van den nieuwen eigenaar gedomicilieesd worden, ook kan worden overcengekomen, dat een bedrag bij een bank geblokkeerd wordt om de wissels daaruit te voldoen; alsdam heeft noch de nicuwe noch de oude eigenaal er verter last mee. l)e betrokkene blijft echter steeds aansprakelijk.

In het voorgaande hebben wij een korte uiteenzetting gegeven van sommige punten, wal'op bij let overgaan van affaires grelet moct worden. Hicrbij zijn. slechts de voornaamste activaen passiva-posten besproken en dan nog slechts bij de overdracht van een bepaalden vorm van ondelneming. Alleen wenschen wij er nog op te wijzen, dat wanncer een som wordt betaald vior de brklanting of goodwill van de zaak, veelal de bepaling wordt gemaakt, dat de rerkooper geen bepaalde soort zaak meer mag beginnen. Dat een en ander alsdan duideljjk en precies in cen overeenkomst omschreven moet worden, laat zich begrijpen. Hicruit kumnen vele kwesties ontstaan, hierop in dit artikel in te gaan is nict mogelijk, het is de stof voor een afzonderlijk artikel. Verder wijzen wij er ten slotte nog nitdrukkelijk op, dat het volgens onze mecning steeds aanbeveling verdient om, zooveel mogelijk, anthentieke akten op to maken, wanneer een zaak wordt overgedragen, Deze hebben zoovele voordeelen boven onderhandsche akten, dat de meerdere kosten niet opwegen tegen de rechtsonzekerheid, welke anders kan optreden.

Mr. H. D. M. KNOL

\section{HET HONORARIUM VAN DEN ACCOUNTANT}

In het Juni-nummer van dit blad schicef $\mathrm{X}$ een lezenswaardig artikel over bovengenoemd onderwerp. Tegen de conclusies van dat altikel heb ik weinig bezwal en ook met de overwegingen die tot die conclusies leiden, kan ik grootendeels meegaan, zoodat ik geen aanlciding zou hebben met den schrijver in discussic te treden, ware het niet dat het uitgangspunt een zeer positieve feitelijke mededeeling bevat, die naar ik meen onjuist is en tegenspraak vereiseht. $X$ stelt ,algemcen staat het beginsel voorop. dat alleen de tijd, aan een opdracht besteed, het eijfer der (accountants) nota bepalen mag" en dat ,alle andere bases (algemeen!) zcer beslist veroordeeld worden".

De schrijver is blijkbaar zóó overtuigd van de juistheid dezer bewering, dat hij iclere bewijsvoering te dien opzichte overbodig acht. Hij houde mij ten goede, dat ik hem de vraag stel ,Waaruit is U dat grobleken?" litteratuur over dit onderwerp is er nict veel. Sternheim geeft in no. 262 van ,De AccountantsControle" cen methode van berekening aan die voor die stelling geen steun bicdt, omdat in het midden gelaten wordt of de "winstopslag"' roor alle clienten en voor alle soorten van opdrachten dezelfice moct zijn, terwijl in de aanteckening bij no. 262 die methode van berekening verlaten wordt en een variabel uurloon gesteld wordt. Daarbij wordt nog de bepcrking gemaakt ,bij r'egclmatig voorkomend werk", en de gehecle paragraaf heeft betıekking op contrôlewerk, niet op alviezen.

Het genoemde leerboek is 7 jaar oud, maar cen latere publi- 